\title{
Effect of dietary intake of trimethylamine on human metabolism of the industrial catalyst dimethylethylamine
}

\author{
Thomas Lundh, Bengt Åkesson, Staffan Skerfving
}

\begin{abstract}
Objectives-The aim was to study the effect of trimethylamine (TMA) on the metabolism of the industrial catalyst dimethylethylamine (DMEA) to ascertain whether biological monitoring of industrial exposure to DMEA is compromised and excretion of the malodorous DMEA in sweat and urine is increased by dietary intake of TMA.
\end{abstract}

Methods-DMEA (0/25 mg) and TMA $(0 / 300 / 600 \mathrm{mg})$ were given simultaneously once weekly for six weeks to five healthy volunteers. Plasma was collected before and one hour after the doses, and urine $0-2,2-4,4-6,6-8$, and 8-24 hours after the doses. Specimens were analysed by gas chromatography with a nitrogen sensitive detector.

Results-Both amines were readily absorbed from the gastrointestinal tract and excreted in urine within 24 hours (DMEA 80\%; TMA 86\%). Oral intake of TMA increased the DMEA content of plasma and urine dose dependently, although there were large individual differences. Plasma and urinary TMA concentrations also increased, but not dose dependently. Moreover, the findings suggested the formation of endogenous TMA, little dealkylation of DMEA and TMA, and considerable first-pass metabolism.

Conclusions-Although intake of TMA reduced N-oxygenation of DMEA and TMA, total urinary DMEA values (aggregate of DMEA and its oxide DMEAO excretion) were unaffected. Thus, monitoring occupational exposure to DMEA by analysis of biological specimens is not confounded by dietary intake of TMA, provided that total urinary DMEA is monitored. Although the increased urinary and hidrotic excretion of DMEA may contribute to body odour problems, they were primarily due to TMA excretion, which is much the greater.

(Occup Environ Med 1995;52:478-483)

Keywords: tertiary aliphatic amines; urine; plasma; biological monitoring

Amines are used in many industrial processes as $\mathrm{pH}$ adjusters - for example, in water borne paints ${ }^{1}$-catalysts for polymeric reactions, corrosion inhibitors, and solvents.
Dimethylethylamine (DMEA) is a low molecular weight aliphatic amine used as a catalyst in the manufacture of polyurethane mould cores in foundries. As it is highly volatile, its concentration in ambient air may be high ${ }^{2-4}$; and as it is strongly alkaline, it may cause irritation of the mucosa and disturbances of vision. ${ }^{25}$

In general, the metabolism of tertiary amines involves two alternative pathways, whereby they undergo biotransformation into their respective amine- $\mathrm{N}$-oxides and $\mathrm{C}$-oxidative dealkylation to secondary amines. ${ }^{6}$ The main metabolic pathway is oxygenation by a flavin-containing mono-oxygenase. In the case of DMEA, the oxide formed is dimethylethylamine-N-oxide (DMEAO).

In humans, genetic regulation of the $\mathrm{N}$ oxygenation of the tertiary aliphatic amine trimethylamine (TMA) is polymorphic and under single gene diallelic control. ${ }^{7}$ Decreased capacity for $\mathrm{N}$-oxygenation of TMA into trimethylamine-N-oxide (TMAO), a hereditary metabolic disorder known as trimethylaminuria (fish odour syndrome), may result in high concentrations of the pungent amine in the urine, sweat, and breath, giving rise to a characteristic and offensive odour. ${ }^{7}$ Moreover, enzymatic oxygenation capacity may become overwhelmed. Thus, doses of $600 \mathrm{mg}$ TMA given orally to healthy volunteers were found to result in reduction of the excreted fraction of TMAO. ${ }^{8}$

Both tertiary and secondary amines and their amine- $\mathrm{N}$-oxides are excreted in urine, and to some extent also in the sweat. The aggregate concentration of DMEA and DMEAO ( $\Sigma$-DMEA) either in plasma or urine has been shown to be a good indicator of exposure to DMEA, and might be a useful variable for biological monitoring purposes. ${ }^{4}$ However, the presence of TMA - for example, TMA precursors (dietary TMAO or choline) converted to TMA in the gastrointestinal tract-may affect DMEA metabolism by diverting it from the main pathway to alternative ones; and further metabolism of DMEA (for example, dealkylation) might thus compromise biological monitoring based on $\Sigma$-DMEA values.

Although DMEAO is non-odoriferous, DMEA, like TMA, has a pungent, fishy, ammoniacal odour, with low olfactory thresholds of about 0.1 and $2.0 \mu \mathrm{g} / \mathrm{m}^{3}$ for TMA and DMEA, respectively. This is three to four orders of magnitude less than the corresponding values for other low molecular amines such as triethylamine, which is also used 
industrially. Foundry workers who use DMEA as a catalyst also emit an offensive, fishy odour at the end of work (Lundh et al, unpublished observation), which may cause these people a variety of psychological and social problems. There is a possibility that exposure to other tertiary amines or their precursors, by metabolic interference, may exacerbate such problems.

Here we report the effect of dietary intake of TMA on human metabolism of DMEA.

\section{Materials and methods}

SUBJECTS AND STUDY DESIGN

The participants were five healthy male volunteers (subjects $A, B, C, D$, and E), mean age 40 (range 25-55) years, body weight 81 $(70-88) \mathrm{kg}$, and height $1.81(1.75-1.91) \mathrm{m}$, all non-smokers. They were instructed not to eat fish or drink alcohol during the 24 hour period preceding the experiments, and to fast overnight ( $>8$ hours) before being given the amines. A standardised breakfast (one slice of bread and cheese, and one to two cups of coffee) was served after two hours, and a standardised lunch (one ham pie, one slice of bread, and water) after four hours. After eight hours, there were no restrictions on food intake, except avoidance of fish and alcohol. Each subject was given an oral dose of DMEA (25 $\mathrm{mg}, \mathrm{pH}$ adjusted to 7) and TMA hydrochloride (Janssen Chemical, Geel, Belgium, $485 \mathrm{mg}$ or $972 \mathrm{mg}$ in $300 \mathrm{ml}$ water (equivalent to 300 and $600 \mathrm{mg}$ TMA, respectively)). The experiments were performed once a week for six weeks (figure).

Urine was collected in polyethylene bottles, before the start of the experiments, and 2,4 , 6,8 , and 24 hours after the doses of amines. Urine specimens were acidified with concentrated $37 \%$ ( $2 \mathrm{ml} / 100 \mathrm{ml}$ urine) hydrochloric acid ( $\mathrm{HCl}$ ) (Merck, Darmstadt, Germany), and stored at $4^{\circ} \mathrm{C}$ until analysed. Blood samples $(20 \mathrm{ml})$ were collected by venepuncture in evacuated heparinised tubes (Venoject, Terumo Europe NV, Leuven, Belgium), before and one hour after the doses of amines. After 30 minutes, the samples were centrifuged (1500 g, 15 minutes) then $2 \mathrm{ml}$ plasma was acidified with $0.5 \mathrm{ml} 1 \mathrm{M} \mathrm{HCl}$ and stored at $4^{\circ} \mathrm{C}$ until analysed.

The study design was approved by the ethics committee of Lund University, and all five subjects gave their informed consent to participate in the study.

ANALYSIS

The gas chromatographic procedures for determining the concentrations of tertiary amines (DMEA and TMA) in plasma and urine and secondary amines (dimethylamine (DMA) and methylethylamine (MEA)) in urine have been described earlier. ${ }^{9-11}$ For the measurement of TMAO and DMEAO, aliquots of plasma and urine samples were reduced with $1 \mathrm{ml}$ of $3 \%$ titanous chloride in $1 \mathrm{M} \mathrm{HCl}$. The specimens were reacted for one hour and then analysed with the same procedure as for amines, and TMAO and
DMEAO were measured as the increases of TMA and DMEA after reduction.

The day to day variations (relative SDs), based on 12 analyses of spiked plasma specimens were: $5 \%(25 \mu \mathrm{mol} / \mathrm{l})$ for $\mathrm{TMA}, 6 \%$ $(190 \mu \mathrm{mol} / 1)$ for TMAO, $5 \%(57 \mu \mathrm{mol} / \mathrm{l})$ for DMEA, and $5 \%(76 \mu \mathrm{mol} / \mathrm{l})$ for DMEAO. The corresponding values for urine analyses were $4 \%(20 \mu \mathrm{mol} / 1)$ for TMA, 3\% (1500 $\mu \mathrm{mol} / \mathrm{l})$ for TMAO, $3 \%(40 \mu \mathrm{mol} / \mathrm{l})$ DMEA, $4 \%(300 \mu \mathrm{mol} / \mathrm{l})$ for DMEAO, and 3\% (355 $\mu \mathrm{mol} / \mathrm{l})$ for DMA. Calculated TMA recovery and half lives for TMA and TMAO were corrected for baseline values obtained in experiments without doses of amines.

\section{Results}

NO AMINES

Before amines were given, the median plasma concentrations of TMA and TMAO were 11 and $32 \mu \mathrm{mol} / 1$, respectively. There were only minor variations within and between the volunteers in the TMA concentrations (range 6-15 $\mu \mathrm{mol} / \mathrm{l}$ ). The range of TMAO concentrations was wider, 4-97 $\mu \mathrm{mol} / 1$, corresponding to TMAO fractions of $20 \%$ to $91 \%$ (median $72 \%$ ). In all experiments the plasma DMA concentration was below the detection limit of our method $(0.6 \mu \mathrm{mol} / \mathrm{l})$. Neither DMEA nor DMEAO were found in plasma or in urine collected before the experiments, or in the experiments where no DMEA was given.

One hour after the start of control experiments without amines, the median plasma concentrations of TMA and TMAO were about the same as the baseline values (11 and $9 \mu \mathrm{mol} / 1$, respectively; table 1 ). The median TMAO fraction was $50 \%$.

Median 24 hour urinary excretions of TMA and TMAO were 3.4 and $390 \mu \mathrm{mol}$, respectively, the TMAO fraction being $99 \%$. There were only minor variations within and between the volunteers in urinary excretion of TMA and TMAO during the four two-hour periods with standardised diet and in the eight to 24 hour period (table 1 ).

\section{TMA}

One hour after the dose of $300 \mathrm{mg}$ of TMA, the plasma TMA concentration had increased in only one subject. At $600 \mathrm{mg}$ of TMA, there were obvious differences between volunteers varying from top to bottom of the range by a factor of five. The plasma TMAO concentration increased in all subjects, both at $300 \mathrm{mg}$ and $600 \mathrm{mg}$, to median values of 191 and 296 $\mu \mathrm{mol} / \mathrm{l}$, respectively, the respective TMAO fractions being $94 \%$ and $95 \%$.

Median urinary excretion of TMA and TMAO (0-24h) increased, the respective median values being 51 and $4550 \mu \mathrm{mol}$ at the $300 \mathrm{mg}$ dose of TMA and 391 and 8620 $\mu \mathrm{mol}$ at the $600 \mathrm{mg}$ dose. Corrected for urinary excretion during experiments with no dose of amines, median aggregate values for recovery of TMA and TMAO in urine were $85 \%$ and $84 \%$ at TMA doses of 300 and 600 mg, respectively (table 2 ). The median 
Table 1 Median (range) concentration in plasma, urinary excretion, and amine- $N$-oxide fractions of the studied amines and amine- $N$ oxides

\begin{tabular}{|c|c|c|c|c|c|c|c|c|c|c|}
\hline \multicolumn{2}{|c|}{ Dose (mg) } & \multirow[b]{2}{*}{ Sample } & \multirow{2}{*}{$\begin{array}{l}\text { Sampling } \\
\text { time }(h)\end{array}$} & \multicolumn{7}{|l|}{ Median (range) } \\
\hline$T M A$ & $D M E A$ & & & $T M A$ & $T M A O$ & $T M A O \%$ & $D M E A$ & $D M E A O$ & $D M E A O \%$ & $D M A$ \\
\hline 0 & 0 & $\begin{array}{l}\text { Plasma } \\
(\mu \mathrm{mol} / \mathrm{l}) \\
\text { Urine } \\
(\mu \mathrm{mol} / \mathrm{h})\end{array}$ & $\begin{array}{l}0 \\
1 \\
0-2 \\
2-4 \\
4-6 \\
6-8 \\
8-24\end{array}$ & $\begin{array}{l}11(9 \cdot 6-15) \\
11(9 \cdot 1-12) \\
0.17(0.09-0.27) \\
0 \cdot 15(0 \cdot 12-0.25) \\
0.16(0.11-0.24) \\
0 \cdot 16(0.11-0.32) \\
0.15(0.08-0.27)\end{array}$ & $\begin{array}{l}7 \cdot 3(5 \cdot 2-72) \\
9(7 \cdot 4-64) \\
24(14-34) \\
21(15-29) \\
18(16-25) \\
18(16-22) \\
16(7 \cdot 7-27)\end{array}$ & $\begin{array}{l}43(26-88) \\
50(40-85) \\
99(99-99) \\
99(99-99) \\
99(99-99) \\
99(99-99) \\
99(99-99)\end{array}$ & $\begin{array}{l}\text { ND } \\
\text { ND } \\
\text { ND } \\
\text { ND } \\
\text { ND } \\
\text { ND } \\
\text { ND }\end{array}$ & $\begin{array}{l}\text { ND } \\
\text { ND } \\
\text { ND } \\
\text { ND } \\
\text { ND } \\
\text { ND } \\
\text { ND }\end{array}$ & $\begin{array}{l}\text { ND } \\
\text { ND } \\
\text { ND } \\
\text { ND } \\
\text { ND } \\
\text { ND } \\
\text { ND }\end{array}$ & $\begin{array}{l}\text { ND } \dagger \\
\text { ND } \\
18(17-21) \\
19(17-21) \\
21(19-22) \\
23(22-25) \\
20(10-29)\end{array}$ \\
\hline 0 & 25 & $\begin{array}{l}\text { Plasma } \\
(\mu \mathrm{mol} / \mathrm{l}) \\
\text { Urine } \\
(\mu \mathrm{mol} / \mathrm{h})\end{array}$ & $\begin{array}{l}0 \\
1 \\
0-2 \\
2-4 \\
4-6 \\
6-8 \\
8-24\end{array}$ & $\begin{array}{l}10(8 \cdot 6-13) \\
13(8 \cdot 1-14) \\
0 \cdot 15(0 \cdot 11-0.25) \\
0 \cdot 13(0 \cdot 11-0.20) \\
0 \cdot 13(0 \cdot 11-0 \cdot 21) \\
0 \cdot 15(0 \cdot 12-0 \cdot 20) \\
0.15(0.12-0.19)\end{array}$ & $\begin{array}{l}30(10-96) \\
29(16-76) \\
17(11-21) \\
14(9 \cdot 2-21) \\
17(7 \cdot 8-22) \\
19(8 \cdot 4-23) \\
16(13-19)\end{array}$ & $\begin{array}{l}78(51-91) \\
78(65-85) \\
99(98-99) \\
99(99-99) \\
99(99-99) \\
99(98-99) \\
99(99-99)\end{array}$ & $\begin{array}{l}\text { ND } \\
\text { ND (ND-0.14) } \\
0.40(0.12-0.96) \\
0.07(0.04-0.38) \\
0.02(0.02-0.19) \\
\text { ND (ND-0.07) } \\
\text { ND }\end{array}$ & $\begin{array}{l}\text { ND } \\
11(6-13) \\
67(51-74) \\
39(33-46) \\
14(11-23) \\
6 \cdot 2(5 \cdot 5-12) \\
1 \cdot 2(1 \cdot 0-2 \cdot 1)\end{array}$ & $\begin{array}{l}\text { ND } \\
100(99-100) \\
99(98-100) \\
100(99-100) \\
100(99-100) \\
100(99-100) \\
100(100-100)\end{array}$ & $\begin{array}{l}\text { ND } \\
\text { ND } \\
21(17-23) \\
17(16-19) \\
20(19-25) \\
23(22-27) \\
21(19-23)\end{array}$ \\
\hline 300 & 0 & $\begin{array}{l}\text { Plasma } \\
(\mu \mathrm{mol} / \mathrm{l}) \\
\text { Urine } \\
(\mu \mathrm{mol} / \mathrm{h})\end{array}$ & $\begin{array}{l}0 \\
1 \\
0-2 \\
2-4 \\
4-6 \\
6-8 \\
8-24\end{array}$ & $\begin{array}{l}10(7 \cdot 3-12) \\
12(9 \cdot 1-27) \\
20(5 \cdot 1-104) \\
2 \cdot 9(1 \cdot 6-43) \\
1 \cdot 0(0 \cdot 59-15) \\
0 \cdot 44(0 \cdot 39-6 \cdot 0) \\
0 \cdot 28(0 \cdot 16-0 \cdot 70)\end{array}$ & $\begin{array}{l}33(13-52) \\
191(155-253) \\
909(459-1124) \\
616(539-795) \\
264(222-401) \\
165(116-261) \\
35(32-70)\end{array}$ & $\begin{array}{c}80(52-83) \\
94(85-95) \\
98(82-99) \\
100(93-100) \\
100(96-100) \\
100(98-100) \\
99(99-100)\end{array}$ & $\begin{array}{l}\text { ND } \\
\text { ND } \\
\text { ND } \\
\text { ND } \\
\text { ND } \\
\text { ND }\end{array}$ & $\begin{array}{l}\text { ND } \\
\text { ND } \\
\text { ND } \\
\text { ND } \\
\text { ND } \\
\text { ND }\end{array}$ & $\begin{array}{l}\text { ND } \\
\text { ND } \\
\text { ND } \\
\text { ND } \\
\text { ND } \\
\text { ND }\end{array}$ & $\begin{array}{l}\text { ND } \\
\text { ND } \\
26(22-31) \\
20(19-26) \\
19(18-21) \\
23(21-31) \\
19(8 \cdot 3-23)\end{array}$ \\
\hline 300 & 25 & $\begin{array}{l}\text { Plasma } \\
(\mu \mathrm{mol} / \mathrm{l}) \\
\text { Urine } \\
(\mu \mathrm{mol} / \mathrm{h})\end{array}$ & $\begin{array}{l}0 \\
1 \\
0-2 \\
2-4 \\
4-6 \\
6-8 \\
8-24\end{array}$ & $\begin{array}{l}12(5 \cdot 9-15) \\
16(8 \cdot 6-29) \\
35(18-119) \\
6.0(2 \cdot 9-44) \\
1.6(0 \cdot 72-12) \\
0.66(0.52-5 \cdot 8) \\
0.26(0.09-0.64)\end{array}$ & $\begin{array}{c}19(3 \cdot 8-30) \\
191(125-194) \\
826(665-1191) \\
724(320-749) \\
300(167-416) \\
174(128-295) \\
39(19-69)\end{array}$ & $\begin{array}{c}57(20-80) \\
91(84-96) \\
97(85-99) \\
99(94-99) \\
100(97-100) \\
100(98-100) \\
99(99-100)\end{array}$ & $\begin{array}{l}\mathrm{ND}^{\star} \\
0.31(0.12-1 \cdot 5) \\
3.6(2 \cdot 7-10) \\
0.84(0.37-4.5) \\
0 \cdot 20(0.08-1.2) \\
0.07(\mathrm{ND}-0.57) \\
\text { ND }\end{array}$ & $\begin{array}{l}\text { ND } \\
6 \cdot 8(5 \cdot 2-11) \\
49(27-72) \\
37(19-47) \\
16(8 \cdot 8-21) \\
7 \cdot 7(5 \cdot 6-14) \\
1 \cdot 5(0 \cdot 79-2 \cdot 6)\end{array}$ & $\begin{array}{l}\text { ND } \\
97(77-99) \\
93(72-96) \\
98(89-98) \\
99(95-99) \\
99(96-100) \\
100(100-100)\end{array}$ & $\begin{array}{l}\text { ND } \\
\text { ND } \\
29(24-37) \\
21(10-35) \\
24(16-29) \\
26(21-32) \\
25(8 \cdot 9-26)\end{array}$ \\
\hline 600 & 0 & $\begin{array}{l}\text { Plasma } \\
(\mu \mathrm{mol} / \mathrm{l}) \\
\text { Urine } \\
(\mu \mathrm{mol} / \mathrm{h})\end{array}$ & $\begin{array}{l}0 \\
1 \\
0-2 \\
2-4 \\
4-6 \\
6-8 \\
8-24\end{array}$ & $\begin{array}{c}9 \cdot 3(7 \cdot 1-12) \\
20(14-59) \\
156(44-221) \\
28(18-129) \\
7 \cdot 3(3 \cdot 2-51) \\
1 \cdot 9(1 \cdot 4-21) \\
0 \cdot 43(0 \cdot 33-2 \cdot 1)\end{array}$ & $\begin{array}{c}55(47-64) \\
296(222-407) \\
1358(655-2324) \\
1363(1121-1549) \\
587(397-932) \\
318(246-546) \\
74(46-150)\end{array}$ & $\begin{array}{l}86(83-88) \\
95(79-95) \\
92(75-96) \\
98(90-99) \\
99(95-99) \\
99(96-100) \\
99(99-100)\end{array}$ & $\begin{array}{l}\text { ND } \\
\text { ND } \\
\text { ND } \\
\text { ND } \\
\text { ND } \\
\text { ND }\end{array}$ & $\begin{array}{l}\text { ND } \\
\text { ND } \\
\text { ND } \\
\text { ND } \\
\text { ND } \\
\text { ND } \\
\text { ND }\end{array}$ & $\begin{array}{l}\text { ND } \\
\text { ND } \\
\text { ND } \\
\text { ND } \\
\text { ND } \\
\text { ND } \\
\text { ND }\end{array}$ & $\begin{array}{l}\text { ND } \\
\text { ND } \\
29(23-34) \\
28(27-34) \\
24(16-33) \\
26(21-30) \\
20(17-25)\end{array}$ \\
\hline 600 & 25 & $\begin{array}{l}\text { Plasma } \\
(\mu \mathrm{mol} / \mathrm{l}) \\
\text { Urine } \\
(\mu \mathrm{mol} / \mathrm{h})\end{array}$ & $\begin{array}{l}0 \\
1 \\
0-2 \\
2-4 \\
4-6 \\
6-8 \\
8-24\end{array}$ & $\begin{array}{l}12(6 \cdot 9-15) \\
27(9 \cdot 0-48) \\
99(29-203) \\
25(11-139) \\
6 \cdot 7(2 \cdot 2-43) \\
2 \cdot 7(1 \cdot 0-19) \\
0.52(0 \cdot 24-1 \cdot 7)\end{array}$ & $\begin{array}{c}42(20-73) \\
218(201-376) \\
1445(542-1814) \\
1444(1205-1540) \\
700(556-815) \\
312(290-569) \\
79(59-132)\end{array}$ & $\begin{array}{l}79(63-88) \\
91(81-96) \\
95(73-97) \\
98(90-99) \\
99(95-100) \\
99(97-100) \\
99(99-100)\end{array}$ & $\begin{array}{l}\text { ND } \\
0.64(0.12-1 \cdot 2) \\
6 \cdot 2(2 \cdot 1-9.0) \\
1.5(0.51-6.9) \\
0.34(0 \cdot 11-2 \cdot 2) \\
0 \cdot 12(0.05-0.93) \\
\text { ND (ND-0.05) }\end{array}$ & $\begin{array}{l}\text { ND } \\
4 \cdot 5(2 \cdot 2-8 \cdot 0) \\
43(12-53) \\
44(37-55) \\
20(14-23) \\
8 \cdot 3(7 \cdot 6-17) \\
1 \cdot 5(1 \cdot 4-3 \cdot 0)\end{array}$ & $\begin{array}{l}\text { ND } \\
91(64-97) \\
90(58-94) \\
97(84-99) \\
98(91-99) \\
99(95-99) \\
99(99-100)\end{array}$ & $\begin{array}{l}\text { ND } \\
\text { ND } \\
31(25-42) \\
27(23-39) \\
23(11-72) \\
25(13-52) \\
25(15-38)\end{array}$ \\
\hline
\end{tabular}

${ }^{\star} \mathrm{ND}=$ Not detected $(<0.04 \mu \mathrm{mol} / \mathrm{l}$ in plasma and $0.005 \mu \mathrm{mol} / \mathrm{h}$ in urine for a 0.11 sample); fnot detected $(<0.6 \mu \mathrm{mol} / \mathrm{l})$.

TMAO fraction was $99 \%$ at the $300 \mathrm{mg}$ dose of TMA, but only $95 \%$ at the $600 \mathrm{mg}$ dose.

Compared with the 0-24 hour period, the effect of TMA on $\mathrm{N}$-oxygenation was even more obvious during the first two-hour period, the median TMAO fraction in urine being $98 \%$ at the $300 \mathrm{mg}$ dose of TMA and $92 \%$ at the $600 \mathrm{mg}$ dose (table 1). Differences between volunteers were noted. The TMAO fraction declined from the baseline level of $99 \%$ (no TMA given) to $82 \%$ at $300 \mathrm{mg}$ of TMA and $75 \%$ at $600 \mathrm{mg}$ in the most affected subject (A), compared with the respective values of $99 \%, 99 \%$ (no decline), and $96 \%$ in the least affected subject (E) (figure).

DMEA

In only one subject (A), did the plasma DMEA concentration at one hour after the dose of DMEA exceed the detection limit of

Table 2 Recovery from the doses of DMEA and TMA of the total amine and amine- $N$-oxide excreted to urine within 24 hours

\begin{tabular}{|c|c|c|c|}
\hline \multicolumn{2}{|c|}{ Dose given } & \multirow[b]{2}{*}{$\begin{array}{l}D M E A \\
\% \text { of dose } \\
\text { median (range) }\end{array}$} & \multirow[b]{2}{*}{$\begin{array}{l}T M A \\
\% \text { of dose } \\
\text { median (range }\end{array}$} \\
\hline $\begin{array}{l}D M E A \\
(m g)\end{array}$ & $\begin{array}{l}T M A \\
(m g)\end{array}$ & & \\
\hline 0 & 0 & - & - \\
\hline 25 & 0 & $81(74-85)$ & - \\
\hline 0 & 300 & & $85(73-91)$ \\
\hline 25 & 300 & $79(66-80)$ & $88(65-104)$ \\
\hline 0 & 600 & - & $84(83-91)$ \\
\hline 25 & 600 & $80(76-81)$ & $87(83-90)$ \\
\hline
\end{tabular}

$0.04 \mu \mathrm{mol} / 1$ (table 1 ). The median plasma DMEAO concentration was $11 \mu \mathrm{mol} / \mathrm{l}$, and the DMEAO fraction $100 \%$.

Median urinary excretion (0-24 hours) of DMEA was $1.0 \mu \mathrm{mol}$ and that of DMEAO $275 \mu \mathrm{mol}$. The median $\Sigma$-DMEA value represented $81 \%$ of the DMEA dose given (table 2). The DMEAO fraction was $100 \%$ in all cases except subject $A$, where it was $1-2 \%$ lower.

Synchronised doses of $25 \mathrm{mg}$ of DMEA and 300 or $600 \mathrm{mg}$ of TMA had no effect on the plasma concentrations of TMA and TMAO, which were comparable with the respective values obtained in experiments where no DMEA was given.

By contrast, the median DMEA concentration was higher $(0.31 \mu \mathrm{mol} / 1$ at a TMA dose of $300 \mathrm{mg}$, and $0.64 \mu \mathrm{mol} / \mathrm{l}$ at a dose of 600 $\mathrm{mg}$ ) than in experiments where DMEA but no TMA was given, although there were considerable individual differences, values varying from top to bottom of the range by a factor of 10 (table 1). N-oxygenation of DMEA was affected by TMA in a dose dependent manner, the median plasma DMEAO concentration one hour after DMEA was given being $6.8 \mu \mathrm{mol} / 1$ at a TMA dose of $300 \mathrm{mg}$, and 4.5 $\mu \mathrm{mol} / 1$ at a TMA dose of $600 \mathrm{mg}$, and the respective median DMEAO fractions were $97 \%$ and $91 \%$.

Median urinary excretion of DMEA (0-24 hours) increased after intake of TMA to $9 \cdot 4$ $\mu \mathrm{mol}$ at a TMA dose of $300 \mathrm{mg}$ and to 16 
The DMEAO and the $T M A O$ fractions excreted in urine for subjects who had the highest (subject $A$ ) and lowest (subject $E$ ) metabolic interaction. Also shown is the experimental schedule of the oral doses of $D M E A$ and TMA to the five volunteers.
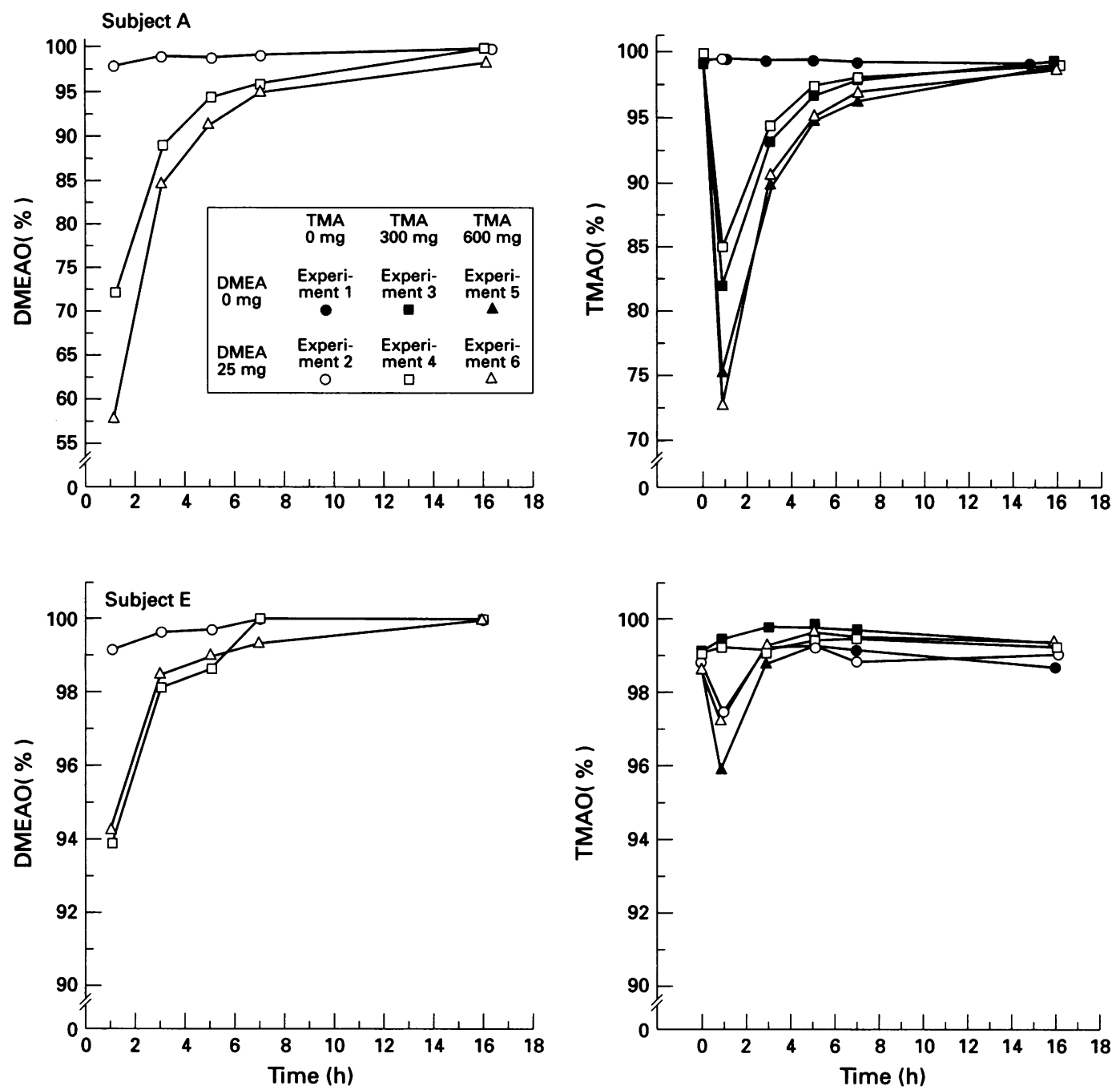

$\mu \mathrm{mol}$ at a dose of $600 \mathrm{mg}$. Excretion of DMEAO was about the same at both doses (254 and $257 \mu \mathrm{mol}$, respectively), as was median $\Sigma$-DMEA ( $79 \%$ and $80 \%$, respectively, table 2). The median DMEAO fraction decreased to $97 \%$ at the $300 \mathrm{mg}$ dose of TMA and to $94 \%$ at the $600 \mathrm{mg}$ dose.

As with TMA, the effect on the N-oxygenation of DMEA was most obvious during the first two hour period. The median DMEAO fraction in urine decreased from $100 \%$ to $93 \%$ at a TMA dose of $300 \mathrm{mg}$ and to $90 \%$ at a dose of $600 \mathrm{mg}$ (table 1). Subject E was again the least affected and subject $A$ the most affected (figure).

\section{PLASMA CONCENTRATION V URINARY EXCRETION}

There was a close correlation between the plasma DMEA concentration one hour after the doses and urinary DMEA excretion during the first two-hour period (Spearmans's rank correlation; $r_{\mathrm{s}}=0.95, \mathrm{P}=0.004$ ), and between plasma and urinary concentrations of DMEAO $\left(r_{\mathrm{s}}=0.79, \mathrm{P}=0.003\right)$.

HALF LIVES IN URINE

During the period, two to eight hours after the doses of TMA and DMEA, the half lives were $1 \cdot 2-2 \cdot 0$ hours for DMEA, $1 \cdot 5-2 \cdot 5$ hours for
TMA, 2-7-3.5 hours for DMEAO, and 2.5-4.0 hours for TMAO. The concentration of the TMA dose was not a determinant of the half lives of DMEA or DMEAO in urine, nor was the concentration of the DMEA dose a determinant of the half lives of TMA or TMAO.

\section{EXCRETION OF DMA}

Multiple regression analysis showed urinary DMA excretion to have increased significantly in response both to TMA and to DMEA during the first two-hour period after the doses (95\% confidence interval (95\% CI) $4 \cdot 4-7 \cdot 4$ $\mu \mathrm{mol}$ for $300 \mathrm{mg}$ of TMA, 0.7 to $5.6 \mu \mathrm{mol}$ for $25 \mathrm{mg}$ of DMEA), but only to TMA in the second two-hour period $(95 \%$ CI 3.6-7.0 $\mu \mathrm{mol}$ for $300 \mathrm{mg}$ of TMA). At the $5 \%$ level there was no significant increase in urinary DMA excretion during any other period. Moreover, there was no significant interaction between TMA and DMEA in any of the periods.

\section{Discussion}

In the absence of TMA, both TMA and TMAO were present in plasma and in urine, the TMAO fraction being much lower in plasma than urine. Oral intake of TMA 
increased the plasma concentration and urinary excretion of an oral dose of DMEA in a dose-dependent manner although there were large differences between volunteers. The $\Sigma$ DMEA was unaffected. Plasma concentration and urinary excretion of TMA was also increased by doses of TMA, although the increases were not dose-dependent. The relatively small dose of DMEA had no effect on TMA metabolism. Urinary excretion of DMA was slightly but significantly increased by doses of both TMA and DMEA.

DMEA was given orally to simplify the experimental procedure, and TMA itself was given rather than any of the precursors occurring in foodstuffs to avoid results being confounded by individual differences in gastrointestinal formation of TMA. The $\Sigma$ DMEA in plasma obtained with the $25 \mathrm{mg}$ oral dose of DMEA corresponds to that obtained in workers exposed to DMEA present in ambient air at a concentration of about $10 \mathrm{mg} / \mathrm{m}^{3} .^{4}$ Moreover, dietary intake of marine fish may contribute about $2000 \mathrm{mg}$ of the TMA precursor TMAO ${ }^{1213}$ and Al-Waiz and coworkers have reported about $50 \%$ of TMAO given orally to be reduced to TMA by metabolic retroversion. ${ }^{14}$

As is the case with inhaled DMEA, ${ }^{415}$ in our study oral DMEA was oxygenated to DMEAO, but to a greater extent, the DMEAO fraction was excreted in urine over 24 hours. This was $99 \%$ compared with the value of $90 \%$ after inhalation previously reported by our group. ${ }^{15}$ This suggests that first pass metabolism of DMEA was significant in the present study.

Both TMA and TMAO were found in plasma and in urine of subjects who had not been given amines, a noteworthy finding being that the TMAO fraction was lower in plasma than in urine. After being given TMA, the TMAO fraction in plasma increased considerably, which suggests endogenous formation of TMA, probably deriving from metabolism of choline, lecithin, and carnitine, or other precursors, before passage through the liver. That urinary TMAO was higher than urinary TMA is probably explained by reabsorption of TMA, as both the amine and its oxide are efficiently excreted into urine.

Simultaneous doses of TMA reduced DMEA metabolism in a dose-dependent manner, probably due to competition of DMEA and TMA for the N-oxygenation process. Moreover, there were individual differences in DMEA metabolism, one subject showed a reduction at the $300 \mathrm{mg}$ dose of TMA, which suggests that his amine metabolism may have been modified by ordinary dietary intake of TMA, but he had no history of body odour induced by amines. In accordance with previous findings by Al-Waiz and coworkers, ${ }^{8}$ we found that doses of TMA also inhibit N-oxygenation of TMA. Thus, the metabolic capacity of the mono-oxygenase is limited.

The plasma $\Sigma$-DMEA value one hour after the doses was reduced when TMA and DMEA were given simultaneously, but as the urinary $\Sigma$-DMEA value was unaffected the reduction in plasma was probably due to a decreased rate of gastrointestinal uptake of DMEA rather than an increase in distribution volume.

Urinary excretion of DMA increased after TMA was given at either dose, which indicates $1 \%$ to $2 \%$ demethylation of TMA. During the first two-hour period, a small but significant contribution of DMA from demethylation of DMEA was found. Moreover, there was no demethylation of DMEA to MEA (MEA values < $0.01 \%$ ).

Our findings suggest that normal lifestyle factors may interfere with human metabolism of the industrial tertiary amine DMEA. The increased physiological concentrations of DMEA are not associated with any toxicological effects. ${ }^{12}$ The increased elimination of amine in breath, sweat, and urine may cause workers exposed to DMEA a variety of psychological and social problems. Thus, for instance, staff at our laboratory clearly recognised the amine odour of subjects exposed to $25 \mathrm{mg}$ DMEA. In the experiments where TMA was given the odour became even more pungent, although there was no appreciable difference in odour depending on the dose of TMA or on the presence or absence of a simultaneous dose of DMEA.

Thus, the findings suggest that ordinary dietary intake would not be a confounding factor in biological monitoring of industrial exposure to DMEA. Demethylation of DMEA, an alternative pathway for DMEA metabolism in the presence of TMA, was of minimal importance. Moreover, the concentration of the TMA dose was not a determinant of $\Sigma$-DMEA. In all likelihood, the effect of TMA dose on the plasma $\Sigma$-DMEA values is only a problem when assessing DMEA uptake through the gastrointestinal tract rather than through the lungs.

Thus, provided $\Sigma$-DMEA is determined as well, occupational exposure to DMEA may be assessed by analysis of urine or plasma specimens. Although, for ethical reasons, the present series was small, the results were consistent and permit the conclusion to be drawn that intake of TMA affects human metabolism of the industrial catalyst, DMEA.

The study was supported by the Swedish Work Environment Fund and the Medical Faculty, Lund University. The technical assistance of Ms Asa Amilon is acknowledged.

1 Hansen MK, Larsen M, Cohr K-H. Waterborne paints. A review of their chemistry and toxicology and the results of determinations made during their use. Scand $¥$ Work Environ Health 1987;13:473-85.

2 Albrecht WN, Stephenson RL. Health hazards of tertiary amine catalysts. Scand $尹$ Work Environ Health 1988;14: 209-19.

3 Åkesson B, Skerfving S, Ståhlbom B, Lundh T Metabolism of triethylamine in polyurethane foam man-
ufacturing workers. Am $\mathcal{F}$ Ind Med 1989;16:211-22.

4 Lundh T, Ståhlbom B, Âkesson B. Dimethylethylamine in mould core manufacturing exposure, metabolism, and biological monitoring. Br Э Ind Med 1991;48:203-7.

5 Ståhlbom B, Lundh T, Florén I, Âkesson B. Visual disturbances in humans at experimental and occupational exposure to dimethylethylamine. Brf Ind Med 1991;48: 26-29.

6 Bickel $\mathrm{MH}$. N-Oxide formation and related reactions in drug metabolism. Xenobiotica 1971;1:313-9.

7 Al-Waiz M, Ayesh R, Mitchell SC, Idle JR, Smith RL. A genetic polymorphism of the N-oxidation of trimethylamine in humans. Clin Pharmacol Ther 1987;42:588-94. 
8 Al-Waiz M, Ayesh R, Mitchell SC, Idle JR, Smith RL. Trimethylaminuria: the detection of carriers using a trimethyl

9 Lundh T, Ståhlbom B, Ákesson B. Methods for the determination of dimethylethylamine and dimethylethyl-Noxide in air, plasma and urine samples. Int $\mathcal{f}$ Environ Anal Chem 1991;44:81-6.

10 Svensson B-G, Akesson B, Paulsson K. Urinary excretion of methylamines in men with varying intake of fish from the baltic sea. F Toxicol Environ Health 1994; $11: 411-20$.

11 Lundh T, Åkesson B. Gas chromatographic determination of primary and secondary low-molecular-mass aliphatic amines in urine using derivatization with isobutyl chloroformate. F Chromatogr 1993;617:191-6.
12 Al-Waiz M, Ayesh R, Mitchell SC, Idle JR, Smith RL. Trimethylaminuria ("fish-odour syndrome"): a study of an affected family. Clin Science 1987;74:231-6.

13 Ayesh R, Smith RL. Genetic polymorphism of trimethylamine N-oxide. Pharmacol Ther 1990;45:387-401.

14 Al-Waiz M, Ayesh R, Mitchell SC, Idle JR, Smith RL Disclose of the metabolic retroversion of trimethylamine $\mathrm{N}$-oxide in humans: a pharmacogenetic approach. Clin Pharmacol Ther 1987;42:608-12.

15 Ståhlbom B, Lundh T, Akesson B. Experimental study on the metabolism of dimethylethylamine in man. Int Arch Occup Environ Health 1991;63:305-10.

16 Al-Waiz M, Mitchell SC, Idle JR, Smith RL. The metabolism of ${ }^{14} \mathrm{C}$-labeled trimethylamine and its $\mathrm{N}$-oxide in man. Xenobiotica 1987;17:551-8. 